\title{
Tangut (Xi Xia) Studies in the Soviet Union: Quinta Essentia of Russian Oriental Studies
}

\author{
Sergey D mitriev* (R ussia)
}

\begin{abstract}
race to the famous discovery of Piotr Kozlov's expedition, a very 7 rich collection of various Tangut books in a mausoleum in the dead city of Khara-Khoto was found in 1908, and almost all the texts in the Tangut language were then assembled in Saint-Petersburg. Because of this situation Russian Tangutology became one of the most important in the world very fast, and Russian specialists, especially Alexej Ivanov, did the first steps to understanding the Tangut language and history, which had for a very long time been hidden from humanity.

This tradition persisted in the Soviet Union. Nikolaj Nevskij in 1929 returned to Russia from Japan, where he had stayed after 1917, mainly to continue his Tangut researches. But in 1937, during Stalin's Purge, he was arrested and executed, Ivanov too. The line of tradition was broken for almost twenty years, and only the 1960s saw the rebirth of Russian Tangutology. The post-War generation did a gigantic work, raising Tangut Studies to a new level. Unfortunately, they almost had no students or successors.

The dramatic history of Tangut Studies in Russia could be viewed like a real quinta essentia of the fate of Oriental Studies in Russia - but all the changes and tendencies are much more demonstrative of this example.
\end{abstract}

Keywords: Tangut Studies, Sinology, Russia, Nikolaj Nevskij, Oriental Studies

\section{Introduction}

The history of Tangut Studies is not very well known even amongst Orientalists, and that is very much a pity - it seems that even now it is a domain which conserved pretty well many specific features of the so called Classical Orientalism, lost by other lines of Oriental Studies. Even now Tangut Studies are very much like

* The Project is supported by RHSF Grant № 12-21-10000 «Sinology - the Oral History», International Academic Contest by RHSF (Russia) - National Scientific Council (Taiwan) 
Orientalism a hundred years ago: it is populated by several dozens of researchers who in most cases personally know other colleagues; the general bibliography of Tangut Studies consists of four or five hundreds positions, so, unlike other fields, researcher can easily follow all new publications in their domain. Russian Tangutology has one more very important mark - his history, despite relatively few populated, is extremely dramatic and rich of strong characters and tragic destinies. That is why I am sure that it is a history worth to be known.

\section{A History of Russian Tangutology}

For the first time the name Tangut was mentioned in a runic funerary inscription of Bilge Khagan, a ruler of the East Turkic Khaganate, dated AD 735. It is clear that already at that time the people, who spoke one of the languages of the Qiangic subgroup of Tibeto-Burman group, lived at the North-West of the Tibetan plateau and on the territory of the modern Chinese province Gansu. In the second part of $7^{\text {th }}$ Century the Tangut leaders were strong enough to be considered among the strongest and dangerous vassals of Chinese empire: they got a prestigious right to bear the family name of Chinese emperors respectively from the Tang and Song dynasties. At the end of the $10^{\text {th }}$ Century the Tanguts, semi-dependent on the Song Empire, established a completely independent state, mentioned in Chinese sources as the Western Xia (Xi Xia 西夏) (the Tangut name of their country was most likely The State of High Whiteness (or The State of White and Lofty) (蘚莱晦 Phôn mbin lhia $\left.{ }^{I}\right)$ ). Successful campaigns against their neighbours (Kitans, Uighurs, Chinese, Tibetans) gave to the Tanguts the opportunity to create a relatively big and self-sufficient state. In 1038 the Tangut ruler, known by his Chinese name Yuanhao 元吴, proclaimed his state an Empire, and himself an emperor. ${ }^{2}$ One of the important signs of independence for the states of the Pax Sinica at that time was the invention of a new writing - e.g. the Kitans and the Jurchens also invented their own writing.

As far as we know, it was a purely political decision - it seems that a big part of the Tanguts spoke and read Chinese, many others also used the Tibetan alphabet - and after an introduction of the new writing, they very likely continued to use Chinese or Tibetan in everyday life. The intellectual elite of the Tangut state was almost certainly bilingual (or even trilingual, including Tibetan), ${ }^{3}$ and

1 For the pronunciation of Tangut characters we use a system elaborated by Mihail V.Sofronov (see Mihail V. Sofronov, Grammatika tangutskogo jazyka (A Tangut language grammar), Moscow: Nauka, Glavnoe izdatel'stvo vostochnoj literatury, 1968, vol. I, 69-144.

2 For more details, see Evgenij I. Kychanov, Ocherk istorii tangutskogo gosudarstva (A sketch of a history of Tangut state), Moscow: Nauka, Glavnoe izdatel'stvo vostochnoj literatury, 1968; Li Fanwen (ed.), Xi Xia tongshi (General history of Western Xia), Yinchuan: Ningxia renmin chubanshe, 2005.

${ }^{3}$ According to the texts, in the Tangut state a big part of population was Chinese; they were 
all parts of the Tangut culture and life were formed under a strong influence of Chinese culture. So, according to Yuanhao's order Tangut writing was developed in 1036-1038 by philologists under the guidance of an emperor counsellor and relative Yeli Renrong 野利仁榮, mentioned in Tangut sources as the Great Tutor I-rie (磁誼). ${ }^{4}$ It is clear that the philologists from the workgroup were under a deep influence of Chinese science and traditions; part of the group could even be Chinese. In spite of this, Tangut writing was created not as an unrepugnant follower of Chinese writing, but as its strong rival - with the use of all the fine elaborated instruments of Chinese philology and lexicology of that time, the Tangut scientists were capable to create a very well elaborated and considered logograph writing system, based on original and very non-Chinese fundamental ideas. ${ }^{5}$ Of course, it wasn't mandatory - but a degree of originality in national writing was a symbol of real independence, gained by the Tangut state.

In 1227 the Tangut state was destroyed by the Mongol hordes of Genghis Khan. The Tanguts themselves, however, survived and managed to contribute a formation of the greatest empire of the Old World - the Mongol empire. Among the dignitaries of the Yuan dynasty (1260-1368), ${ }^{6}$ whose biographies can be seen in official annals of the Yuan shi 元史 ("History of Yuan"), we can easily find many officials of Tangut origin. It seems that vanquished Tanguts were successful intermediaries between Mongols and Tibetans and helped greatly with the spreading of Buddhism among Mongol nobles. An interesting model of interaction hetween an emperor and a State Teacher - the head of the Buddhist numerous between bureaucracy of all ranks too.

4 To picture the multicultural and polyethnical nature of Tangut state, let me add that I-rie (Yeli) was very probably a Tangut transcription of Yelü 耶律 - a family name of a ruling dynasty of Kitan empire Liao 遼 (915-1125). We don't know if the creator of Tangut writing was Kitan by culture and language, or his family was already assimilated by Tanguts. More about Tangut writing, see Nikolaj. A. Nevskij, Tangutskaja pismennost' i ejo fondy (Tangut writing and his corpus), in Nikolaj A. Nevskij, Tangutskaja filologia, Vol. I, 74-94.

5 Fortunately, we have dictionaries (especially etymological "Sea of characters" (·iwə ngôn 對踏); for chinese edition see Shi Jinbo et al. (eds.), Wenhai yanjiu (Study of “Sea of characters"), Beijing: Zhongguo shehui kexue chubanshe, 1983; about Russian translation see above) and possess a very detailed explanation of basic methodology of Tangut writing, proposed by creators of this writing themselves. And it's very clear that Tangut script is one of the most interesting and charming writing systems - a logographic writing, that didn't emerge and transform during centuries (even thousands of years) following constantly changing systems of transitional rules (and most part of those rules was never explained or even written). On the opposite the Tangut system of writing was invented by several intellectuals in a very short amount of time. That work based on clear logic and a strong ambition to make it not à la chinois.

6 State ruled by Mongol rulers, descendants of Chingis-khan. Emperor of Yuan was a formal head of all chingisid states, since the second half of XIII ${ }^{\text {th }}$ century formed in enormous spaces from Russian princedoms, Balkans and Syria to South Siberia, Korea and Burma. Yuan emperor ruled mainly in China and some neighbour lands, territory of former Tangut state included. 
sangha of empire - was very likely borrowed by Mongols from the Tangut state. ${ }^{7}$ When Mongol rule collapsed, the situation for the Tanguts turned bad - the land of the Tanguts became a part of China after some cruel campaigns led by the Chinese Ming dynasty (1368-1644). Ming emperors did their best to prevent a new invasion of Mongols in China, and one of their policies was the suppression of ethnic and religious groups that had been Mongol allies at the time of the Yuan rule. Tangut regions were considered suspicious - the border with the steppe was close, and the Tanguts were clearly among the "collaborators". So, the Ming armies devastated the Tangut cities, the Tanguts were decimated and scattered. The Tangut language and writings could be maintained in some monasteries for several generations (may be up to the $16^{\text {th }}$ Century), but its extinction was inevitable. That was an end to the Tangut civilisation - the people were dispersed and assimilated by Chinese, Mongols or Tibetans, ${ }^{8}$ cities were burned and repopulated by Chinese or turned into a desert.

However, it was not the end: habent sua fata libelli.

As already mentioned, the Tanguts were known under this name very early, already in the VIII ${ }^{\text {th }}$ century. But it was not their proper name - they called themselves Mi-ndziwo 柇細, where the second character is "man", and the first one, $\mathrm{Mi}$ is a logogram especially elaborated to determinate both Tangut language and Tangut people. ${ }^{9}$ So, "Tangut" is a Turkic word, very early adopted by Mongols, who continued to use it even after the destruction of the Tangut state and the fading of the Tangut people and their culture. We know that $19^{\text {th }}$ century Mongols called the tribes of warlike nomads in north-eastern Tibet (region of Kukunor, north of historical region of Amdo) by the word "Tanguts". Some of these nomads were Tibetans (like Goloks, for example) but many were Mongols that were assimilated by Tibetans.

The word "Tangut" was relatively early also perceived by the Russians - in the first period of their penetration through Siberia they acquired information about China and its neighbours mainly via Mongols. In the $17^{\text {th }}$ and $18^{\text {th }}$ centuries in Russian (and scientific Latin of Russian scholars) the word "Tangut" meant

7 See Ruth W. Dunnell, The Hsia Origins of the Yüan Institution of Imperial Preceptor, Asia Major, 3rd ser. (1992), 5.1, 85-111.

8 In the border area of Sichuan/Yunnan/Tibet autonomous region still exists some Qiangic languages; many of them (especially of rGyalrongic branch) seems to be very close to Tangut. See James A. Matisoff, "Brightening" and the place of Xixia (Tangut) in the Qianqic branch of Tibeto-Burman, in Lin Yin-chin et al. (eds.) Studies in Sino-Tibetan Languages: Papers in Honor of Professor Hwang-cherng Gong on His Seventieth Birthday, Language and Linguistics Monograph Series W-4, Taipei: Institute of Linguistics, Academia Sinica, 2004, 327-352; Xiang Bolin (Guillaume Jacques), Jiarong yu yanjiu (Study of rGyalron languages), Beijing: Minzu chubanshe, 2008.

9 See Nikolaj A. Nevskij, Tangutskaja filologia, Vol. II, 133. 
"Tibet". ${ }^{10}$ In the same time this word became relatively popular between western botanists and was used for the creation of scientific names of some plants (for example, Rheum tanguticum, Aconitum tanguticum. Clemats tangutica and many others); we strongly suspect that in most cases reverend scientists were confused by their Russian colleagues and thought rather about Tibet.

Later this mistake was corrected: in an important book by a famous Russian investigator Nikolaj Przhevalsky (Николай Михайлович Пржевальский) (18391888) called Mongolia and the Land of Tanguts (1875-76), "Tangut" meant (as in Mongolian) a nomad population of North-eastern Tibet. But, of course, it did not appeal to the "real" historical Tanguts, who by that time seemed completely forgotten by the entire world.

If we talk about the world though, in the end of the $19^{\text {th }}$ century some of the Tangut texts were already discovered and examined by western scholars. In 1870 an English missionary and colleague of James Legge, Alexander Wylie (1870), published an article about an inscription in six languages on the gates of a fortress named Jủyongguan 居庸關 near Beijing. The inscription was dated back to 1345 and consisted of six practically identical texts in Sanskrit, Tibetan, Mongolian (in so called square script), Uighur, Tangut and Chinese. Wylie was absolutely right in his suggestion that in all the texts there was one part the same: it was the transcription of Sanscrit dhāranī. However, he was wrong about the Tangut part he decided that it was Jurchen writing. In 1882 a French diplomat, historian and linguist Gabriel Devйria (1882) published an article about Jurchen inscription on a stele from Yantai 宴臺. In that paper Gabriel Devйria remarked that the inscription on the gates of Jüyongguan definitely was not in Jurchen, but that it could be, he supposed, in Xi Xia (Tangut) writing. In 1895, under the supervision of Prince Roland Bonaparte (1895) all the texts of the Jüyongguan gates were published - a dhāranī part of the Tangut text was analyzed by the great French Sinologist Edouard Chavannes. Even in that edition, the Tangut origin of the text was only a very uncertain assumption. Only in 1898 the problem was finally solved - Devйria (1898) published a bilingual inscription from a Dayunsi temple 大雲寺 in Liangzhou, and one part of that inscription was in the same writings as the unrecognized text in Junyongguan. The text in the Chinese part said that the inscription was made in 1094 in Xi Xia state writings. The question thus was

${ }^{10}$ That is why, unfortunately, we cannot begin the history of Russian Tangut Studies with a brilliant work of Gerard Friedrich Müller (great Russian historian of German origin, "father" of Siberian history (1705-1783), was known in Russia as Fiodor Ivanovich Miller (Фёдор Иванович Миллер)) “De scriptis tanguticus in Sibiria repertis commentatio" (see Gerard F. Müller, De scriptis tanguticus in Sibiria repertis commentatio Gerardi Friderici Mülleri, Commentarii Academiae scientiarum imperialis petropolitanae, X (ad annum MDCCXXXVIII), Petropoli (Saint-Petersburg): Typis Academiae, 1766, 420-468). That work, among other things, contain some Tibetan texts, found by Müller during his travel in South Siberia 
solved, but the text remained undecoded and unread - the available inscriptions were too small to become a "Rosetta stone".

In 1904 a translator of the French embassy in Beijing, M. G. Morisse (1904), published his study on a Tangut text of Lotus sutra (Saddharma Pundarīka Sūtra). M. G. Morisse bought this text near White pagoda temple (白塔寺) that had been ravaged by Boxers - one of the few buildings from the Yuan dynasty that remained in Beijing. The text was previously studied by an unknown Chinese scholar - many Tangut characters were provided with handwritten notes and Chinese translations. Thanks to this unknown Tangutologist, Morisse could make many important remarks about the structure of a Tangut phrase; he decoded some characters and discovered a pronunciation of some others (mainly of special characters, elaborated for phonetic transcription of Sanscrit or Chinese words). $\mathrm{He}$ also very reasonably assumed that Tangut must be a language of the Tibetan group. It was a big achievement, but further progress seemed almost impossible - the Buddhist texts did not provide any relevant material for the decoding of the language and writings, and, what was much more sad -the entire corpus of texts in the Tangut language seemed to be limited to these few texts. In short, scientists did not have an instrument for the decoding and almost nothing to decode.

But Providence was benevolent to the Tanguts. In 1907 Piotr K. Kozlov (Пётр Кузьмич Козлов) (1863-1935), apprentice and follower of Prjevalskij, organized a new expedition named Mongol-Sichuanese, to explore the western border of China. One of the targets were the ruins of the abandoned city Khara-Khoto. ${ }^{11}$ During excavations in this city in 1908 and 1909 Kozlov found hundreds of paintings, statues (which are in the Saint-Petersburg Hermitage museum now ${ }^{12}$ ),

11 Khara-Khoto ( $\mathrm{HPaH}\left(\mathrm{C}^{\mathrm{b}}\right)$, in Mongolian - "Black City", located in western Inner Mongolia. It was founded in 1032 and was a centre of north provinces of Tangut state, one of fortresses on the frontier with nomads. In Tangut times the city had a name Źiẹnia像譬,"Black water”, due to the nearest river. Mongols still call this river Ejin Gol - so the Tangut name remained. In 1372 the city was besieged, taken and ravaged by Ming Chinese forces. During the siege Chinese forces barraged a river and forced its waters to change the course. That was fatal for the city - in a very short time it was swept away by the desert and abandoned by all inhabitants who survived the seizure. (For more details see Piotr K. Kozlov, Mongolia i Amdo i mertvyj gorod Khara-Khoto (Mongolia and Amdo and a dead city of Khara-Khoto), 2 ed., Moscow: Gosudarstvennoe izdanie geograficheskoj literatury, 1947, 80-82; Nikolaj A. Nevskij, O naimenovanii tangutskogo gosudarstva (About a name of Tangut state), in Nikolaj A. Nevskij, Tangutskaja filologia..., Vol. I, 40).

${ }^{12}$ See, for ex. Kira F. Samosiuk, Buddijskaja jivopis iz Khara-Khoto XII-XIV vv. Mejdu Kitaem i Tibetom. Kollekcija P. K. Kozlova (Buddhist painting from Khara-Khoto, XII-XIV ${ }^{\text {th }}$ centuries. Between China and Tibet. P. K. Kozlov's collection), Saint-Petersburg: Gosudarstvennyj Ermitag, 2006. 
and, above all - hundreds of Tangut texts of various kind. ${ }^{13}$ And then the Tanguts could speak again - the desert had saved their words from the destructive forces of time.

Those findings were extremely valuable not only for Tangut culture, but also for Russian Tangut studies, which had not existed before. The main corpus of Tangut texts was transferred to the Asiatic Museum in Saint-Petersburg; ${ }^{14}$ of course, the Russian scholars where the first who had the possibility to study this new and extremely challenging material. And we think that Kozlov's luck did not only determine the boom of Tangutology (especially in Russia), but also a name for a new line of Oriental Studies. Before the findings in Khara-Khoto the term "Tangut" was rarely used by Western scholars - they preferred to call newly discovered language and writings by the Chinese word "Xi Xia". And the reason for the Chinese term is very clear - before Kozlov's findings an overwhelming part of the sources about the Tanguts was in Chinese. The Mongolo-Turcic term "Tangut" was relatively popular only among Russian erudites and we suppose that it is quite probable that an advantage, gained by Russian scholars (thank to Kozlov's findings) actually gave Tangutology its name. ${ }^{15}$

The results of Khara-Khoto discoveries appeared very quickly. Young Sinologist and a professor of Saint-Petersburg university, Aleksej I. Ivanov (Алексей Иванович Иванов) (1878-1937) found in the just arrived Tangut xilographs a Tangut-Chinese dictionary Mi źa ngwu ndzie mbu pia ngu nie 貓嗈鰍棔腎橒萩睞/番漢合時掌中珠 (Timely pearl in the palm of Tangut and Chinese languages), compiled in 1190 by a Tangut scholar called Kwəlderiephu 茖䨪埶怐. ${ }^{16}$ That finally was a real Rosetta stone (characters were not only translated, but also transcribed by phonetically equal Chinese characters). In 1909 Ivanov published some results of his study. ${ }^{17}$ This little article (and full of mistakes, due to haste of the author, who had hurried to inform the world about new possibilities in decoding the Tangut language) was an important impulse for

${ }^{13}$ About excavations, see Piotr K. Kozlov, Mongolia i Amdo, 75-87. A Tangut collection of Institut of oriental manuscripts of Russian academy of sciences, which are mainly consisted from texts, brought by P. Kozlov, numbers more then 8000 units of issue (see Zinaida I. Gorbacheva and Evgenij I. Kychanov (comp.), Tangutskie rukopisi i ksilografy (Tangut manuscripts and xylographs), Moscow: Izdatel'stvo vostochnoj literatury, 1963, 17).

${ }^{14}$ After Kozlov's findings a certain number of Tangut texts were also obtained by scientific institutions of different countries, and this process continues. But the Saint-Petersburg collection is still unrivaled in quantity and especially in quality of objects.

15 Indeed, "Tangutology" as a term is no better than "Xi Xia studies": both of them use foreign names of this people. Something like Mi studies or Milogy would be much more precise, we suppose. But science isn't always about logic.

${ }^{16}$ In many books he is mentioned under a Chinese variant of his name, Gule Maocai骨勒茂 才, which fact, of course, is rather strange.

${ }^{17}$ Aleksej I. Ivanov, Zur Kenntnis der Hsi-Hsia Sprache, Bulletin de l'Académie Impériale des Sciences de St.-Pétersbourg, VI série, Tome III, Saint-Petersbourg, 1909, 1221 - 1233. 
Tangut studies around the world. In 1916 was published an important research of Berthold Laufer (1874-1934), a famous American anthropologist of German origin, ${ }^{18}$ with many right conclusions about the Tangut language; also, in these years were published the first researches of Chinese Tangutologists (among them Luo Fucheng 羅福成 (1885-1960), Luo Fuchang 羅福萇 (1895-1921) and his father, famous philologist Luo Zhenyu 羅振玉 $\left.(1866-1940){ }^{19}\right)$. At the same time, Władysław Kotwicz (Владислав Людвигович Котвич) (1872-1944), a Russian and Polish mongolist and turcologist, ${ }^{20}$ began his work with the Tangut texts.

In 1925 Ivanov was the chief translator at the Soviet embassy in Beijing, but he tried to continue his studies of Tangut. That year he was visited by a Japanologist Nikolaj A. Nevskij (Николай Александрович Невский) (1892-1937), ${ }^{21}$ who

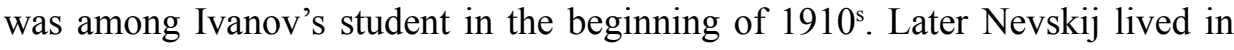
Japan - since 1915, after graduation from Saint-Petersburg university (there he was mainly a student of the Sinologist Vasilij M. Alekseev (1881-1951)), Nevskij was sent to Japan for further studies. After the Russian revolution in 1917 he decided not to return and worked in Japan - especially in the field of language, religion, folklore and customs of the Japanese, Ainu and Ryukuans. In 1927 he also traveled to Taiwan to study the language of Zou鄒 - one of indigenous people

${ }^{18}$ Berthold Laufer, The Si-hia language, a study in Indo-Chinese philology, Toung Pao, Ser. 2, 17. 1, 1916, 1-126.

${ }^{19}$ See, for example: Luo Fucheng, Xi-Xia yi Lianhua-jing kaoshi (A study of Tangut translation of Lotus sutra), S.l., 1919; Luo Fuchang, Xi-Xia guoshu lüeshuo (Brief talk about of Tangut national script), Kyoto: Higashiyama gakusha shirushi, 1914; Luo Zhenyu (ed.), Gule Maocai Fan-Han heshi zhang-zhong zhu (Timely pearl in the palm of Tangut and Chinese languages by Gule Maocai), Tianjin: Yiantang, 1924.

${ }^{20}$ Kotwicz arrived in Saint-Petersburg in 1891 for studying at the university's Oriental faculty. After graduation he stayed in the capital and worked in the Ministry of Finance. Up to the 1917 he combined work in the Ministry with researches and work at the university. From 1900 he headed a department of Mongol philology. He participated in many scientific expeditions to Kalmykia $(1894,1896,1910,1917)$ and Northern Mongolia (1912), where, besides other things, he studied Turcic runic texts. After 1917 Kotwicz tried to organize in Petrograd an Institute of living oriental languages and from 1920 to 1922 he was its director. In 1923 he was elected professor and corresponding member of Academy of sciences. In 1923 he decided to return to Poland, since 1924 he was a head of department of Far Eastern philology at the Lvov University, one of the finest intellectual centers of a pre-war Poland. He became a president of a new formed Polish oriental society (Polskie Towarzystwo Orientalistyczne), since 1927 - a chief editor of «Rocznik Orientalistyczny» (“Orientalist's annual"). See M. Lewicki, Władysław Kotwicz (20.III 1872 - 3.X 1944), Rocznik Orientalistyczny, 16, 1953, XI-XXIX.

${ }^{21}$ About his life see Lidiia I. Gromkovskaya and Evgenij I. Kychanov, Nikolaj Aleksandrovich Nevskij, Moscow: Nauka, Glavnoe izdatel'stvo vostochnoj literatury, 1978. 
of the island..$^{22}$ But we know that since 1923-1924 he began to study the Tangut problems, which was extremely hard as he was so far from Russia. ${ }^{23}$ In 1925 Ivanov gave him some copies of Tangut texts and dictionaries he had brought to Beijing - probably, that was the defining moment and Nevskij decidedly turned to Tangut studies. In 1926 in Osaka he published a research on the Tibetan transcription of Tangut words ${ }^{24}$ (Tibetan handwritten notes can be found in many Tangut texts - it seems that some Tanguts used the Tibetan alphabet in everyday life). But it was more and more clear that for a profound study he had to be in Leningrad and work with Tangut texts directly. Therefore, in the autumn of 1929 Nevskij returned to Leningrad. His wife Mantani Isoko 萬谷磯子 (1901-1937) and their daughter Elena managed to join him only in 1933.

In the first years in Leningrad it seems that Nevskij's dreams came true. $\mathrm{He}$ worked in the Institut of Orientalism in the Academy of Sciences of the USSR (which in 1930 replaced the Asiatic Museum), in the University and in the State Hermitage. He studied ad libitum Tangut manuscripts and xylographs. ${ }^{25} \mathrm{He}$

${ }^{22}$ See Nikolaj A. Nevskij, Materialy po govoram cou (Materials on dialects of Zou language), Trudy Instituta vostokovedenia Akademii nauk SSSR (Papers of the Institute of orientology of the Academy of Sciences of USSR), t. XI, Moscow-Leningrad: Izdatel'stvo Akademii nauk, 1935; more detailed publications was edited many years after his death: see Nikolaj A. Nevskij, Ajnskij folklor. Issledovaniia i teksty (Folklore of Ainu. Researches and texts), Moscow: Nauka, 1972; Nikolaj A. Nevskij, Folklor ostrovov Mijako (Folklore of Miyako islands). Moscow: Nauka, 1978; Nikolaj A. Nevskij, Materialy po govoram jazyka cou. Slovar dialekta severnykh cou (Materials on dialects of Zou language. A dictionary of northern Zou dialect). Moscow: Nauka, Glavnoe izdatel'stvo vostochnoj literatury, 1981. Some œuvres posthumes of Nevskij was collected in Na steklah vechnosti... Nikolaj Nevskij. Perevody, issledovanija, materialy $k$ biografii (On an eternity glasses... Nikolay Nevskij. Translations, researches, biography datas), Peterburgskoe vostokovedenie (St. Petersburg journal of oriental studies). Issue 8. Saint-Petersburg: Peterburgskoe vostokovedenie, 1996, 255-488.

23 Vasilij M. Titianov, who was with Nikolaj A. Nevskij in a prison ward in 1937, remembered that Nevskij told him that his interest toward Tangut language began much earlier, just after Kozlov's expedition; he even told that one of objectives of his journey to Japan in 1915 was to find there a specialist who could help him with decoding of Tangut writing (see Na steklah vechnosti..., 516).

${ }^{24}$ Nikolay Nevsky, A brief manual of the Si-hia characters with Tibetan transcription, Research review of the Osaka Asiatic Society, No.4, March 15, 1926, Osaka: The Osaka Asiatic Society.

${ }^{25}$ Before Nevskij's return the Tangut collections was a field of interest of great Russian linguist Alexandr A, Dragunov (Александр Александрович Драгунов) (1900-1955) - one of the creators of modern theory of Chinese grammar. He published some works about Tangut funds (for ex. see Alexandr A. Dragunov, A catalogue of His-Hsia (Tangut) Works in the Asiatic Museum of Academy of sciences, Leningrad, Bulletin of the National Library of Peiping, Vol. 4,. May-june 1930 (issued in January 1932), № 3, 367-388). But in 1930 he abandoned this work and went to Middle Asia for studies of Dungan (回族) language. He returned to Tangut collections only after the end of the World War II, but this time that was not his cup of tea. Although he described 2720 units of issue of Tangut collection (see Zinaida I. Gorbacheva and Evgenij I. Kychanov (comp.), Tangutskie rukopisi..., 12-17). 
published many papers on Tangut problems in the Soviet Union and China. ${ }^{26}$ In 1935 he became a doctor of science honoris causa. In a famous illustrated book "Den' mira" ("One day of the world"), promoted by Maxim Gorky (1935) as a momentary snapshot of the entire world's life in the same one day (27 September 1935 was chosen) we can find a brief information about professor Nikolay Nevskij, working on a decoding of the Tangut language. Who could ask for more?

But suddenly things changed. Since the summer of 1937 in the Soviet Union had started the terrible period of the Great Purge, when nearly one million persons were executed or died in concentration camps, condemned in various kinds of high treason of the Soviet state. Investigators of the People's Commissariat for Internal Affairs tried to impress their bosses, including Stalin, by enormous plots of spies and traitors, revealed by them. The Institute of Oriental Studies, full of researchers with knowledge of many strange languages, many of them were even abroad, was a too tempting target. An underground group of Japanese spies, organised and coordinated by Nikolay Nevskij was revealed (even an Institute director, famous turcologist, academician Alexandr Samojlovich (Александр Николаевич Самойлович) (1880-1938), was arrested as a member of «Nevskij's group»). ${ }^{27}$ Nevskij was arrested at night of 3-4 October of $1937,{ }^{28}$ in a few days his wife was arrested too. They were condemned and executed on the 24 November of 1937. Alexey I. Ivanov was executed earlier, on 8 October, also as a Japanese spy. We do not even know the place where they are buried. ${ }^{29}$

Russian Tangutology was physically exterminated. ${ }^{30}$ And only after the death of Stalin in 1953 the situation began to change - but the line was broken. In 1955 the young Sinologist Evgenij I. Kychanov (Евгений Иванович Кычанов) (19322013), who had just graduated from the Oriental faculty of Leningrad university, became a graduate student at the Oriental manuscripts sector of the Institute of Oriental Studies (from 1956 - Leningrad filial of Institute) and intended to work in Tangut studies. He had no proper scientific adviser - among the specialists of the Institute there were not any Tangutologists. At that time there were many

${ }^{26}$ The list of intravital publications of Nevskij see Nikolaj A. Nevskij, Tangutskaja filologia..., Vol. I, 14-15.

${ }^{27}$ About a case of Samoilovich see Fedor D. Ashnin, Vasilij M. Alpatov, Dmitrij M. Nasilov, Repressirovannaja turkologija (Repressed turcology). Moscow: Vostochnaia literatura, 2002, 7-20.

${ }^{28} \mathrm{He}$ could not foresee that was the end. Leaded away he said to his wife: "Don't touch the papers on my work desk - I will be back soon".

${ }^{29}$ Many precious materials about life, work and murder of Nikolaj Nevskij was collected in $\mathrm{Na}$ steklah vechnosti..., 486-561.

${ }^{30}$ Konstantin K. Flug (Константин Константинович Флуг) (1893-1942), who studied medieval Chinese books and also worked with the Tangut texts, starved to death during the Leningrad blocade. Some results of his work see Konstantin K. Flug, Istoria kitajskoi pechatnoj knigi Sunskoj epohi X-XIII vv. (History of Chinese printed books of Song time, X-XIII ${ }^{\text {th }}$ centuries), Moscow-Leningrad: Izdatel'stvo Akademii nauk SSSR, 1959. 
rumours that Nevskij was alive and would return - like many who returned in the 1950s from prisons. "Don't worry, Nevskij will be your adviser" - said colleagues to Kychanov. Kychanov and others had to become Tangutologists by themselves. It was not easy.

Up to 1960, the Tangut fond was closed for everyone but Zoia I. Gorbacheva (Зоя Ивановна Горбачёва) (1907-1979), who was its keeper after Nevskij's death. ${ }^{31}$ It was mainly because of the fear that somebody could steal Nevskij's drafts and misappropriate his results, but also because of an absence of specialists who could work there. ${ }^{32}$ In 1960 a huge impact into Tangut Studies was made with strong support of academician Nikolay I. Konrad (Николай Иосифович Конрад) (1891-1970), a friend and a schoolmate of Nevskij - he was also touched by the Purge but survived. Konrad did everything possible to publish a facsimile of the Tangut dictionary, prepared by Nevskij, in two volumes. ${ }^{33}$ It was only a draft that Nevskij had written for personal use, unfinished and unpolished, but it was the first dictionary in the world, ${ }^{34}$ it contained almost all known Tangut characters, with translations, examples, and sometimes phonetics. ${ }^{35}$ The Tangut texts could be read at last. In 1962 for these two volumes Nevskij was postmortem granted the Lenin award. ${ }^{36}$

This publication, just like Ivanov's article about the "Pearl in the palm" in 1909, gave the strongest impulse to Tangut studies in the world, and of course in the Soviet Union, too. The Tangut workgroup was formed in the Leningrad filial of the Institute of Oriental studies at that time. Except for a famous Sinologist Vsevolod S. Kolokolov (Всеволод Сергеевич Колоколов) (1896-1979), all other members were young - Evgenij Kychanov, Mikhail V. Sofronov (Михаил Викторович Софронов) (b. 1929), Ksenia В. Kepping (Ксения Борисовна Кеппинг) (1937-2002), Anatolij P. Terent'ev-Katanskij (Анатолий Павлович

${ }^{31}$ The only exclusion was Alexandr A. Dragunov; he died presumably in 1955.

${ }^{32}$ In 1938 Nevskij's drafts were returned (together with a part of Tangut manuscripts he worked with at the night of arrest) by People's Commissariat for Internal Affairs to the Institute, but only few fellows of the Institute knew where they was hidden. Some of papers were founded only years after; some are still unfounded.

${ }^{33}$ Nikolaj A. Nevskij, Tangutskaja filologia.... Zoia I. Gorbacheva did a big work of preparing of this publication.

${ }^{34}$ We know that rather a big dictionary (3000 characters, more than a half of all) was prepared for publication by Alexey I. Ivanov as early as in 1919; but due to turbulences of revolution and civil war in Russia it wasn't published. In 1922 Ivanov took his dictionary from Academy publishing house. Until 1937 the manuscript was at his home, but after Ivanov's arrest the dictionary was lost.

${ }^{35}$ It seems that Nevskij was really close to the complete reconstruction of Tangut phonetics work was almost done (see Evgenij I. Kychanov, Tangutskie tetradi (Tangut notebooks), in Na steklah vechnosti..., 508-513).

${ }^{36}$ In 2007 the book was edited in Chinese version. See Nie Lishan (Nikolaj A. Nevskij), Xi$\mathrm{Xia}$ yu wenxue (Tangut language philology), in Xi-Xia yanjiu (Tangut studies), 6, Beijing: Zhongguo shehui kexue chubanshe, 2007. 
Терентьев-Катанский) (1934-1998). ${ }^{37}$ Quantity and quality of the members gave to this group an opportunity to explore many important things in a very limited period of time.

In 1963 M. V. Sofronov and E. I. Kychanov published the "Studies on the Tangut language's phonetic", where they offered the first attempt for a phonetic reconstruction of the Tangut language. In 1968 Evgenij I. Kychanov edited a "Sketch of the history of the Tangut state" - the first detailed account of Tangut history in the world. That same year appeared a two-volume Tangut grammar by M. V. Sofronov - also the first scientific grammar of this language and a very important study on the reconstruction of its phonetics. In 1969 Vsevolod S. Kolokolov, Ksenia B. Kepping, Evgenij I. Kychanov and Anatolij P. Terent'evKatanskij as a result of a very complicated work published a translation of the Sea of characters - an etymological dictionary, which is fundamentally important for understanding the principles of Tangut writings.

It was the biggest workgroup in the history of Russian Tangut studies. Their impact, as a team and in individual projects, was abundant and very important. Thanks to them Tangut writing was finally well decoded and Tangut studies achieved a new level in the analysis of sources. ${ }^{38}$

After the 1960s the members of the group mostly worked apart, but still had very good results. ${ }^{39}$ Ksenia Kepping studied many important Chinese texts, translated into Tangut, but mostly was occupied with linguistic questions. ${ }^{40}$ Anatolij P. Terent'ev-Katanskij published some pioneer books about the Tangut

${ }^{37}$ In other countries the Tangut studies also saw a big flourishing at that time, and the majority part of leading Tangutologists of the world are of the same age: Huang Zhenhua 黃 振華 (1930-2003), Li Fanwen 李範文 (b. 1932) and Shi Jinbo史金波 (b. 1940) in China, Nishida Tatsuo 西田龍雄 (1928-2012) in Japan; Gong Hwang-cherng (1934-2010) in Taiwan; Eric Grinstead (b. 1921) in New Zealand; James A. Matisoff (b. 1937) in California. The next generation of scholars, unfortunately, was much less numerous.

${ }^{38}$ We must add that it was also the time when the Tangut studies became popular again - mainly due to Nevskij's Lenin award. In 1963 a documentary ("Sem' vekov spustia" ("Seven centuries later")) about a decoding of Tangut writings was made by Agasi Babajan (b. 1921); programmes about Tanguts were broadcasted on the radio.

${ }^{39}$ We must add that soviet Tangutologists usually enjoyed better opportunities to contact with foreign colleagues or to go abroad - which was practically impossible to other Orientologists: Tangutology was one of the demanded and reputable "brands" of Soviet science.

${ }^{40}$ See, for ex. Ksenia. B. Kepping, Tangutskij jazyk: Morfologija (Tangut language: a Morphology), Moscow: Nauka, Glavnaia redakciia vostochnoj literatury, 1985. During this work she received an important help from famous linguist Sergej E. Iahontov (Сергей Евгеньевич Яхонтов) (b. 1926). For the full list of Kepping's publications see Bibliografiia rabot K. B. Kepping (Bibliogragy of K. B. Kepping) http://kepping.net/raboty-16.htm, accessed 23 February 2014. 
civilisation ${ }^{41}$ and translated a very important Tangut glossary -Mixed characters (his works were finished by Mihail V. Sofronov). ${ }^{42}$ Evgenij I. Kychanov was a recognized elder of the Soviet Tangutologists - not only because he made a very impressive career, ${ }^{43}$ but also for his enormous impact on Tangut studies. Among nearly 350 publications ${ }^{44}$ we must especially highlight a brilliant translation and study of a Tangut code from the $12^{\text {th }}$ Century ${ }^{45}$ and an impressive Tangut-RussianEnglish Dictionary ${ }^{46}$ which in many aspects exceeds Nevskij's work.

Unfortunately, all these wonderful scholars of this fantastic generation had almost no students - mainly because of political and economical turbulence in Russia which started in the 1980s and of course was not propitious for fundamental science, especially for the humanities. Unfortunately the field of Russian Tangutology nowadays is nearly deserted and almost no one comes to replace the glorious generation. ${ }^{47}$

${ }^{41}$ See Anatolij P. Terent'ev-Katanskij, Knizhnoe delo v gosudarstve tangutov (po materialam kollekcii P. K. Kozlova) (Book industry in Tangut's state (on the materials of P. K. Kozlov's collection)), Moscow: Nauka, Glavnaia redakciia vostochnoj literatury, 1981; Anatolij P. Terentev-Katanskij, S Vostoka na Zapad. Iz istorii knigi i knigopechataniia v stranah Centralnoj Azii VIII-XIII vekov (From East to West. From the history of book a book printing in the countries of Central Asia of $8^{\text {th }}-13^{\text {th }}$ Centuries), Moscow: Nauka, Glavnaia redakciia vostochnoj literatury, 1990; Anatolij P. Terentev-Katanskij, Materialnaja kultura Si Sia. Po dannym tangutskoj leksiki i ikonograficheskomu materialu (Material culture of Xi Xia. On the data of Tangut lexica and iconographic material), Moscow: Nauka, Vostochnaia literatura, 1993.

${ }^{42}$ See Anatolij P. Terent'ev-Katanskij, Mihail V. Sofronov (eds.), Smeshannye znaki \{trioh chastej mirozdaniia\} (Mixed characters \{of three parts of the universe\}), Moscow: Vostochnaia literatura RAN, 2002.

${ }^{43}$ From 1978 he was a head of Far East sector of Leningrad filial of the Institute of Oriental studies; in 1991 became a vice-director and from 1996 to 2003 headed that Institut's filial.

${ }^{44}$ Not all of them are about Tangut history - most are consecrated to different questions of Chinese or Central Asian history. The most complete list of Evgenij I. Kychanov's publication see Irina F. Popova (ed.), Tanguty v Centralnoj Azii. Sbornik statej v chest 80-letija professora E. I. Kychanova (Tanguts in Central Asia. Collected articles in honour of Professor E. I. Kychanov 80th Anniversary), Moscow: Vostochnaia literatura, 2012, 15-57.

${ }^{45}$ Evgenij I. Kychanov (ed.), Izmenennyj i vnov' utverzhdennyj kodeks deviza carstvovaniia Nebesnoe procvetanie (1149-1169) (Changed and newly approved code of reign of Heavenly prosperity (1149-1169)), Vol. I-IV, Moscow: Nauka, Glavnoie izdatel'stvo vostochnoj literatury, 1987-1989.

${ }^{46}$ Evgenij I. Kychanov, Shintaro Arakawa (eds.), Tangut Dictionary. Tangut-Russian-EnglishChinese Dictionary. Kyoto: Faculty of Letters, Kyoto University, 2006.

${ }^{47}$ I know only one important younger Russian tangutologist - Kirill Y. Solonin (Кирилл Юрьевич Солонин) (b. 1969), head of the Far Eastern philosophy and culturology department of Faculty of Philosophy of Saint-Petersburg University, who mainly studies Tangut Buddhism. For ex., see Kirill Y. Solonin, The Chan Teaching of Nanyang Huizhong (-775) in Tangut Translation, Medieval Tibeto-Burman Languages IV, Leiden: Brill, 2012, 267-345. 


\section{Conclusion}

Russian Tangutology has passed through all the important stages which are inherent to the so called classical Orientalism. The first Russian Tangutologists were more rather brave travelers and adventurers, actors of the Great Game, than armchair scientists. We can easily put Piotr Kozlov in the same line with Sir Marc Aurel Stein or Sven Hedin. On the next stage we saw among them some of the finest and brilliant minds, equals to Paul Pelliot or Wang Guo-wei, keen geniuses capable of giving impetus to their science forward even under the pressure of very hard circumstances.

In the years of the Great Purge Russian Tangutology was a part of Russian Oriental Studies, a part of Russian history, and brilliant minds became martyrs. Progress was stopped for years with a bullet of an executioner. In Tangut studies this terrible image was only more obvious - due to the small number and extreme value of each person involved. The next generation, just like in Russian Sinology, was numerous and talented - but the gap between generations was even more clear than in Chinese studies - the previous generation was physically exterminated. Young scholars had to teach themselves and they became good heirs - we only can imagine, what could they have achieved if their predecessors had still been alive.

Nowadays, like in other lines of Oriental sciences in Russia, we - again see the gap between generations and so far there is no solution to this problem. What will be the future of Tangut studies in Russia? Will it conserve its oldfashioned and familiar features, so rare in modern science? Is not this charming archaism a great risk for this science indeed? Would the Tangut writings fall silent again? We will see.

As a final remark I will try to explain why this paper was written. Of course, a history of everything is interesting and somehow useful, but why would someone who is not a Russian tangutologists have to care about Russian Tangutology? Maybe this topic is way too specific? Maybe, but I do not think so. First of all, as I have said above, Tangutology is a very good and demonstrative image, which can be used to understand the basic lines and fluctuations of a history of all Russian Orientology in the $20^{\text {th }}$ Century. Secondly, I suppose that every scientific tradition, especially in the field of humanities, is absolutely crucial to be known to new generations of researchers; without this knowledge about our scientific ancestors we cannot go further. And, last but not least, I think that in our time, when the biggest problem of a scholar is in most cases a low salary or troubles with obtaining of a new grant, it is very useful to remember those who were able to literally give their lives for a possibility to study a new field - which was very specific and absolutely not beneficial indeed. We owe them. 


\section{References}

Ashnin, Fedor D., Alpatov, Vasilij M., Nasilov, Dmitrij M. 2002. Repressirovannaja turkologija (Repressed turcology). Moscow: Vostochnaia literature.

Bibliografiia rabot K. B. Kepping (Bibliogragy of K. B. Kepping). 2014. http://kepping.net/raboty-16.htm, accessed 23 February 2014.

Bonaparte, Roland, Prince, ed. 1895 Documents de l'époque mongole des $X I I I^{e}$ et XIV e siècles. Inscriptions en six langues de la porte de Kiu-Yong Koan, près Pékin; lettres, stèles et monnaies en écritures Oü̈goure et 'Phags$\mathrm{Pa}$ dont les originaux ou les estampages existent en France. Paris: Gravé et imprimé pour l'auteur, 1895.

Clauson, Gerard. 1964. The Future of Tangut (Hsi Hsia) Studies. Asia Major, New ser., 11.1, 54-77.

Golovachev, Valentin C., Kuznecova-Fetisova Marina E. (eds.) 2014. "Interviu s Kychanovym E. I. (Interview with Evgenij I. Kychanov)". http://politics.ntu. edu.tw/RAEC/comm2/ra27.pdf, accessed 28 January 2014.

Gorbacheva, Zinaida I. and Kychanov, Evgenij I. (comp.) 1963. Tangutskie rukopisi $i$ ksilografy (Tangut manuscripts and xylographs). Moscow: Izdatel'stvo vostochnoj literatury.

Gromkovskaya, Lidiia I. and Kychanov, Evgenij I. 1978 Nikolaj Aleksandrovich Nevskij. Moscow: Nauka, Glavnoe izdatel'stvo vostochnoj literatury.

Devéria, Gabriel. 1883. Examen de la stèle de Yen-t'aï. Dissertation sur les caractères d'écriture employés par les Tartares Jou-tchen. Extraite du Hounghue-in-yuan, traduite et annotée. Revue de l'Extrême-Orient, publiée sous la direction de M. Henri Cordier. Première année, 1882. 1.2. Paris, 173-186.

Devéria, Gabriel. 1898. L'écriture du royaume de Si-Hia ou Tangout. Extrait des Mémoires présentés par divers savants a l'Académie des inscriptions et belles-lettres, Ire série, tome XI, Ire partie. Paris.

Devéria, Gabriel. 1898. Stèle Si-Hia de Leang-tcheou. Journal Asiatique ou Recueil de mémoires d'extraits et de notices relatifs a l'histoire, a la philosophie, aux langues et a la littérature des peuples orientaux. IXe série, tome XI, n 1 , Janvier-Février. Paris, 53-74, 1 pl.

Dragunov, Alexandr A. 1932. "A catalogue of His-Hsia (Tangut) Works in the Asiatic Museum of Academy of sciences, Leningrad". Bulletin of the National Library of Peiping, Vol. 4,. May-june 1930 (issued in January 1932), № 3, 367-388. 
Dunnell, Ruth W. 1981. "Tangut Studies in the Soviet Union: State of the Field (1981)". Bulletin of Sung and Yuan Studies, 17, 101-105.

Dunnell, Ruth W. 1992. "The Hsia Origins of the Yüan Institution of Imperial Preceptor”. Asia Major, 3rd ser., 5.1, 85-111.

Flug, Konstantin K. 1959. Istoria kitajskoi pechatnoj knigi Sunskoj epohi $X-X I I I v v$. (History of Chinese printed books of Song time, X-XIII ${ }^{\text {th }}$ centuries). Moscow-Leningrad: Izdatel'stvo Akademii nauk SSSR.

Ivanov, Aleksej I. 1909. "Zur Kenntnis der Hsi-Hsia Sprache”. Bulletin de l'Académie Impériale des Sciences de St.-Pétersbourg. VI série, Tome III. $1221-1233$.

Kepping, Ksenia. B. 1985 Tangutskij jazyk: Morfologija (Tangut language: a Morphology), Moscow: Nauka, Glavnaia redakciia vostochnoj literatury.

Kepping, Ksenia B., Kolokolov, Vsevolod S., Kychanov, Evgenij I. and Terent'ev-Katansky, Anatolij P. (eds.) 1969. More pis'men (Sea of characters). Parts I-II. Moscow: Glavnaia redakciia vostocnoj literatury.

Kozlov, Piotr K. 1947 Mongolia i Amdo i mertvyj gorod Khara-Khoto (Mongolia and Amdo and a dead city of Khara-Khoto). 2 ed. Moscow: Gosudarstvennoe izdanie geograficheskoj literatury.

Kychanov, Evgenij I. 1968. Ocherk istorii tangutskogo gosudarstva (A sketch of a history of Tangut state). Moscow: Nauka, Glavnoe izdatel'stvo vostochnoj literatury.

Kychanov, Evgenij I. (ed.) 1987-1989. Izmenennyj $i$ vnov' utverzhdennyj kodeks deviza carstvovaniia Nebesnoe procvetanie (1149-1169) (Changed and newly approved code of reign of Heavenly prosperity (1149-1169)). Vol. I-IV. Moscow: Nauka, Glavnoie izdatel'stvo vostochnoj literatury.

Kychanov, Evgenij I. 1996. "Tangutskie tetradi (Tangut notebooks)". In "Na steklah vechnosti... Nikolaj Nevskij. Perevody, issledovanija, materialy $\mathrm{k}$ biografii (On an eternity glasses... Nikolay Nevsky. Translations, researches, biography datas)". Peterburgskoe vostokovedenie (St. Petersburg journal of oriental studies). Issue 8. Saint-Petersburg: Peterburgskoe vostokovedenie, 508-513

Kychanov, Evgenij I. 2005. "Ot "bolshogo nabora" do "bolshogo razgona" (From "big conscription" to "big dispersing")". In Vospominanija vypusknikov Vostochnogo fakulteta Leningradskogo (Sankt-Peterburgskogo) gosudarstvennogo universiteta poslevoennyh let (Memoirs of graduates from Oriental faculty of Leningrad (Saint-Petersburg) state university of post-war 
years). Saint-Petersburg: Izdatel'stvo Sankt-Peterburgskogo universiteta, 279-287.

Kychanov, Evgenij I., Arakawa, Shintaro (eds.). 2006. Tangut Dictionary. Tangut-Russian-English-Chinese Dictionary. Kyoto: Faculty of Letters, Kyoto University.

Laufer, Berthold. 1916. The Si-hia language, a study in Indo-Chinese philology. T'oung Pao, Ser. 2, 17. 1, 1-126.

Lewicki, M. 1953. Władysław Kotwicz (20.III 1872 - 3.X 1944). Rocznik Orientalistyczny, 16, 1953, XI-XXIX.

Li, Fanwen (ed.) 2005. Xi Xia tongshi (General history of Western Xia). Yinchuan: Ningxia renmin chubanshe, 2005.

Luo, Fuchang. 1914. Xi-Xia guoshu lüeshuo (Brief talk about of Tangut national script). Kyoto: Higashiyama gakusha shirushi.

Luo, Fucheng. 1919. Xi-Xia yi Lianhua-jing kaoshi (A study of Tangut translation of Lotus sutra). S.1.

Luo, Zhenyu (ed.). 1924. Gule Maocai Fan-Han heshi zhang-zhong zhu (Timely pearl in the palm of Tangut and Chinese languages by Gule Maocai). Tianjin: Yiantang.

Matisoff, James A. 2004. "“'Brightening” and the place of Xixia (Tangut) in the Qianqic branch of Tibeto-Burman”. In Lin Yin-chin et al. (eds.) Studies in Sino-Tibetan Languages: Papers in Honor of Professor Hwang-cherng Gong on His Seventieth Birthday. Language and Linguistics Monograph Series W-4. Taipei: Institute of Linguistics, Academia Sinica, 2004, 327-352.

Morisse, M. G. 1904. Contribution préliminaire a l'étude de l'écriture et de la langue Si-Hia, par M. G. Morisse, Interprète de la Légation de France à Pékin. Extrait des Mémoires présentés par divers savants à l'Académie des inscriptions et belles-lettres, Ire série, tome XI, 2, Paris.

Müller, Gerard F. 1766. "De scriptis tanguticus in Sibiria repertis commentatio Gerardi Friderici Mülleri”. In Commentarii Academiae scientiarum imperialis petropolitanae. X (ad annum MDCCXXXVIII). Petropoli (Saint-Petersburg): Typis Academiae, 420-468.

$\mathrm{Na}$ steklah vechnosti. 1996. "Nikolaj Nevskij. Perevody, issledovanija, materialy k biografii (On an eternity glasses... Nikolay Nevsky. Translations, researches, biography datas)". Peterburgskoe vostokovedenie (St. Petersburg journal of oriental studies). Issue 8. Saint-Petersburg: P 239-560. 
Nevskij, Nikolaj A. 1935. Materialy po govoram Cou (Materials on dialects of the Zou language). Trudy Instituta vostokovedenia Akademii nauk SSSR (Papers of the Institute of orientology of the Academy of Sciences of USSR), $t$. $X I$. Moscow-Leningrad: Izdatel'stvo Akademii nauk.

Nevskij, Nikolaj A. 1960. Ocherk istorii tangutovedenij (A sketch of the history of Tangut Studies). In Nevskij, Nikolay A. Tangutskaja filologia (Tangut philology). Moscow: Izdatel'stvo vostochnoj literatury. Vol. I-II. Vol. I, 19-32.

Nevskij, Nikolaj A. 1960. O naimenovanii tangutskogo gosudarstva (About a name of Tangut state). In Nevskij, Nikolay A. Tangutskaja filologia (Tangut philology). Moscow: Izdatel'stvo vostochnoj literatury. Vol. I-II. Vol. I, 33-51.

Nevskij, Nikolaj A. 1960. Tangutskaja filologia (Tangut philology). Moscow: Izdatel'stvo vostochnoj literatury. Vol. I-II.

Nevskij, Nikolaj A. 1960. Tangutskaja pismennost' $i$ ejo fondy (Tangut writing and his corpus). In Nevskij, Nikolay A. Tangutskaja filologia (Tangut philology). Moscow: Izdatel'stvo vostochnoj literatury. Vol. I-II. Vol. I, 74-94.

Nevskij, Nikolaj A. 1972. Ajnskij folklor. Issledovaniia i teksty (Folklore of Ainu. Researches and texts), Moscow: Nauka.

Nevskij, Nikolaj A. 1978. Folklor ostrovov Mijako (Folklore of Miyako islands). Moscow: Nauka.

Nevskij, Nikolaj A. 1981. Materialy po govoram jazyka cou. Slovar dialekta severnykh cou (Materials on dialects of Zou language. A dictionary of northern Zou dialect). Moscow: Nauka, Glavnoe izdatel'stvo vostochnoj literatury.

Nevsky, Nikolay. 1926. "A brief manual of the Si-hia characters with Tibetan transcription". Research review of the Osaka Asiatic Society, No.4, March 15. Osaka: The Osaka Asiatic Society.

Nie Lishan (Nikolaj A. Nevskij). 2007. "Xi-Xia yu wenxue (Tangut language philology)". In Xi-Xia yanjiu (Tangut studies), 6, Beijing: Zhongguo shehui kexue chubanshe.

Popova, Irina F. (ed.). 2012. Tanguty v Centralnoj Azii. Sbornik statej v chest 80-letija professora E. I. Kychanova (Tanguts in Central Asia. Collected articles in honour of Professor E. I. Kychanov 80 ${ }^{\text {th }}$ Anniversary). Moscow: Vostochnaia literatura.

Prjevalskiy, Nikolaj M. 1875-1876. Mongoliya i strana tangutov. Trehletnee puteshestvie v vostochnoj nagornoj Azii (Mongolia and the Land of Tanguts. A three-years travel in eastern upland Asia). Vol. I-II. Saint-Petersburg: Tipografija V. S. Balasheva. 
Samosiuk, Kira F. 2006. Buddijskaja jivopis iz Khara-Khoto XII-XIV vv. Mejdu Kitaem i Tibetom. Kollekcija P. K. Kozlova (Buddhist painting from Khara-Khoto, XII-XIVth centuries. Between China and Tibet. P. K. Kozlov's collection). Saint-Petersburg: Gosudarstvennyj Ermitag.

Shi, Jinbo et al. (eds.). 1983. Wenhai yanjiu (Study of "Sea of characters"). Beijing: Zhongguo shehui kexue chubanshe.

Solonin, Kirill Y. 2012. The Chan Teaching of Nanyang Huizhong (-775) in Tangut Translation. Medieval Tibeto-Burman Languages IV. Leiden: Brill, 267-345.

Sofronov, Mihail V. 1968. Grammatika tangutskogo jazyka (A Tangut language grammar). Moscow: Nauka, Glavnoe izdatel'stvo vostochnoj literatury. Vol. I-II.

Sofronov, Mihail V., Kychanov, Evgenij I. 1963. Issledovaniia po fonetike tangutskogo jazyka (predvaritelnye rezultaty) (Studies on the Tangut language's phonetic (preliminary results)), Moscow: Izdatel'stvo vostochnoj literatury.

Terent'ev-Katanskij, Anatolij P. 1981. Knizhnoe delo v gosudarstve tangutov (po materialam kollekcii P. K. Kozlova) (Book industry in Tangut's state (on the materials of P. K. Kozlov's collection)). Moscow: Nauka, Glavnaia redakciia vostochnoj literatury.

Terent'ev-Katanskij, Anatolij P. 1990. S Vostoka na Zapad. Iz istorii knigi i knigopechataniia $v$ stranah Centralnoj Azii VIII-XIII vekov (From East to West. From the history of book a book printing in the countries of Central Asia of $8^{\text {th }}-13^{\text {th }}$ Centuries). Moscow: Nauka, Glavnaia redakciia vostochnoj literatury.

Terent'ev-Katanskij, Anatolij P. 1993. Materialnaja kultura Si Sia. Po dannym tangutskoj leksiki i ikonograficheskomu materialu (Material culture of Xi Xia. On the data of Tangut lexica and iconographic material). Moscow: Nauka, Vostochnaia literatura.

Terent'ev-Katanskij, Anatolij P., Sofronov, Mihail V. (eds.) 2002. Smeshannye znaki \{trioh chastej mirozdaniia\} (Mixed characters \{of three parts of the universe\}). Moscow: Vostochnaia literatura RAN.

Wylie, Alexander. 1870. "On an Ancient Buddhist Inscription at Keu-yung kwan, in North China". The Journal of the Royal Asiatic Society of Great Britain and Ireland, New Ser. 5.1, 14-44.

Xiang, Bolin (Jacques, Guillaume). Jiarong yu yanjiu (Study of Gyalrong languages). Beijing: Minzu chubanshe, 2008. 